\title{
R\&D DIVERSIFICATION IN MNCs: BETWEEN EARNINGS MANAGEMENT AND SHAREHOLDERS INCREASING WEALTH
}

\author{
Abderrazak Dhaoui \\ University of Reims, Champagne-Ardennes, France \\ E-mail: abderrazak.dhaoui@yahoo.fr \\ Received 20 October 2007, accepted 10 June 2008
}

\begin{abstract}
This paper examines the impact of the R\&D geographic diversification on the shareholders' wealth (as measured appreciatively by the firm's market value) and on the earnings management as a mechanism of manager's entrainment. Using a sample of 460 firm-year observations for multinational firms over the 2002-2006 period, we find that the R\&D decentralization may enhance the shareholders' wealth and increase the managers' one. The results show that the R\&D geographic diversification increases the informational asymmetry and support the emergence of the favourable conditions for the earnings management and the managers' entrainment. It may increase the managers' autonomy which likely allows them to manage the result in order to increase their own wealth and destruct the shareholder's one.
\end{abstract}

Keywords: R\&D decentralization, shareholders' wealth, earnings management, MNCs.

\section{Introduction}

Several studies documented that R\&D was beneficial for the shareholders. Recent research found that managers may expropriate shareholders through investment policy (Shleifer and Vishny 1989; Morck R. et al. 1990). The informational asymmetry hypothesis argues that in the presence of intangible assets, R\&D decentralization may enhance shareholders' wealth. In addition, different trends of the literature investigate whether earnings management is hindered or facilitated. For instance, Klein (2002) and Xie et al. (2003) examine boards of directors and find that earnings management is hindered in firms with independent boards and financially literate audit committees. Our study contributes to these trends of literature by analyzing $R \& D$ decentralization policies and examining whether earnings management is facilitated or hindered by this variable. Particularly, we examine how a firm's decision to decentralize R\&D affects whether and how managers maximize their utility through R\&D location decisions. We examine how R\&D decentralization affects negatively the managers' capacity to manage earnings or may support the emergence of the favourable conditions for the earnings management. There is much evidence that asymmetry information facilitates earnings management. In the extrapolation of this hypothesis, R\&D decentralization may be positively related to managers' opportunist behaviour.

Our research is motivated by analysing the different ways in which R\&D decentralization affects shareholders' wealth and encourages managers' capacity to manage earnings. To accomplish this task, we try to examine if the R\&D geographic diversification increases or enhances shareholders' wealth. We also check if there is a positive or negative relationship between this diversification and the earnings management.

The organization of this paper is as follows. Section 1 presents the literature review and discusses the hypothesis. Section 2 examines how the sample is selected and what data are employed in the analysis. Section 3 displays the methodology for the market value and the earnings management estimation and the panel data analysis. The empirical results are shown and discussed in section 4. Finally, section 5 concludes. 


\section{Theoretical background and literature review}

Although the positive and negative attributes of $R \& D$ on the firm performance have been theoretically and empirically examined, the impact of R\&D decentralization on the performance of the multinational companies (MNCs) and on the earnings management remains unknown.

A number of previous studies have examined the impact of firm's R\&D investment on its market value. Myers (1977) notes that R\&D activity is an intangible and often firm-specific asset, producing future growth opportunities. In this way, since that firm value is founded on the financial flow discounting (Chaney and Lewis 1995) and that R\&D expenditures induce significant growth opportunities because they are expected to generate future financial resources, firms characterized by significant $R \& D$ expenditures should exhibit high market value. More recently, Chauvin and Hirschey (1993) have found a significant and positive relationship between $R \& D$ expenditures and market value. They used a sample of 1500 US firms over the 1988-1990 period. Their results suggest that investors evaluate the R\&D investment with a long-term perspective. These results imply that share-price may be significantly and positively related to the increase of $\mathrm{R} \& \mathrm{D}$ spending. In contrast to these studies, Lakonishok et al. (1994) and more recently, Zhang (2007) show that investment growth is negatively related to future stock returns.

In spite of the effectiveness of these studies, the effect of R\&D decentralization on shareholders' wealth and on earnings management remains unknown. Particularly, the question why MNCs disperse their R\&D activity has attracted considerable research (Kuemmerle 1999a and 1999b; Pearce and Singh 1992; Bae and Noh 2001). Traditional explanation links dispersed $\mathrm{R} \& \mathrm{D}$ investments to foreign manufacturing and marketing operations that need technical support (Ronstadt 1978; Pearse and Singh 1992). The improvement of the market value and the earnings management target are not considered as real factors which may likely influence the decentralization decisions. In this context, there are several hypotheses to explain why firms decentralize the $R \& D$ investment. The first one argues that decentralization decisions are designed to enhance shareholders' wealth. This standpoint indicates that the managers' objective is to reduce the effect of failure risk and maximize the organizational efficiency by co-localizing the decision process and the knowledge basis (by extrapolation of the Jensen and Meckling's (1992) study).
The effect of the knowledge dispersion on the decentralization is founded in Hayek's $(1945)^{1}$ study. This author argues that the distribution of knowledge in society calls for decentralization. Jensen and Meckling (1992) argue that the organization's performance depends on the collocation of decisions authority with the knowledge. By extrapolation of the studies of Jensen and Meckling (1992) and Hayek (1945), the distribution of knowledge may affect organization structure of investment and calls to disperse the R\&D activities. The R\&D decentralization may enhance the organisational efficiency and, therefore may be likely beneficial for the shareholders.

\section{Assumption 1: The R\&D decentralization may in- crease the firm market value}

The second standpoint assumes that the managers' objective is to increase the informational asymmetry. The decentralization decision should be primarily motivated by the desire to increase the informational asymmetry to facilitate the earnings management. This argument indicates that managers pursue a non-wealth maximizing behaviour. They are motivated by a desire to increase firm's size in order to maximize their own utilities rather than serve the shareholders' interests.

To increase the informational asymmetry between shareholders and managers, these latter may disperse the R\&D investments. This strategy provides them more autonomy to manage earnings. Since managers' wealth is likely to increase with the firm size (Jensen and Murphy 1990a), they may manage earnings by increasing accounting results. In this perspective, $R \& D$ internationalization may affect negatively the shareholders' wealth. It contributes to increase the wealth transfer from shareholders to managers. If that is the case, investors will evaluate the R\&D investment internationalization with more prudence. They may decrease the share-price which will be significantly and negatively related to the increase of $R \& D$ spending in the diversified subsidiaries of the MNC.

$\mathrm{R} \& \mathrm{D}$ decentralization is adopted when managers try to increase the informational asymmetry. If that is the case, there should be positive association between the asymmetric information and the earnings management. The informational asymmetric hypothesis supposes that only managers observe economic earnings and firm type. In an asymmetric information situation, investors can not directly infer the type of the firm from the available information. Since investors can not observe the economic earnings, they must attempt to

\footnotetext{
1 Cited by Jensen and Meckling (1992: 3).
} 
infer it from reported accounting earnings. This gives managers an incentive to use earnings reports to influence investor's perceptions about the firm value, since that the firm value is based on the present value of the expected future economic earnings (Chaney and Lewis 1995). If that is the case, it may be apparent that firms in which $R \& D$ is decentralized are likely to have more asymmetric information than those where $R \& D$ is centralised because there is a significant association between the informational asymmetries and the geographic diversification (Doukas and Pantzalis 2003). When the investment of the firm is severally diversified, it is presumably more difficult for the shareholders (or even stakeholders) to supervise the managers' behaviour. For this reason, managers dispose to autonomy and may likely manage results to increase their own wealth and destruct the shareholder's one.

Since the international diversity increases the informational asymmetries (Doukas and Pantzalis 2003), companies in which the R\&D activity is decentralized should suffer the highest degree of informational asymmetry and, therefore should exhibit the largest degree of earnings management. As a result, a higher degree of earnings management should be observed in more R\&D decentralised firms. This result indicates, consequently, that firms with decentralized R\&D should have a higher extent of earnings management than firms which centralize this activity because the R\&D decentralization creates additional organizational complexity, which leads to a higher level of informational asymmetry between managers and stockholders.

Given that there is a positive relation between earnings management and informational asymmetry, and that the R\&D decentralization increases the asymmetry level, managers may exploit this additional level of informational asymmetry and engage in a higher degree of earnings management than otherwise would be the case if $R \& D$ is not decentralized. This assumption implies that there is a positive relationship between earnings management and $\mathrm{R} \& \mathrm{D}$ decentralization. While that is the case, the earnings management hypothesis argues that $\mathrm{R} \& \mathrm{D}$ decentralization is not related to increased efficiency but to the maximization of the managers' own utility function. These arguments indicate that $R \& D$ decentralization was not beneficial to the shareholders. In this sense, managers may not act in their principals' interests but rather pursue their own self-interest. Under this scenario, managerial decisions may be understood in the sense of opportunism. The managers use these decisions to influence the way the investors perceive the firm's result or performance.
Lambert (1984) demonstrates that "risk averse" managers have an incentive to smooth economic earnings. Hughes and Schwartz (1989) use informational asymmetry between managers and investors to motivate the choice of inventory accounting methods. The informational asymmetry hypothesis predicts a positive relationship between R\&D decentralization and informational asymmetry. As a result of this there is a positive relationship between earnings management and $R \& D$ decentralization. In the same order of idea, Trueman and Titman (1989) show that managers smooth income because they want investors to perceive that the firm is less risky. Particularly, they smooth reported earnings because they want shareholders to perceive that the firm performs well. For this reason, managers conduct a R\&D decentralized strategy for increasing informational asymmetry. They may exploit this situation and engage in a higher degree of earnings management. This behaviour is explained by the decision to increase the reported earnings because their compensation is related to earnings that they can provide for the shareholders. Thus, by smoothing reported earnings, managers want investors to perceive that the firm is beneficial.

According to this way, the potential investors may anticipate the managers' opportunist behaviour and integrate it during their evaluation of the firm's assets, what induces an underevaluation of the firm's stockprice.

Assumption 2: The R\&D decentralization may increase earnings management and induce the market value destruction

\section{Research design and sample data}

\subsection{Research design}

This section examines the influence of $R \& D$ decentralization on market value and earnings management. These variables may also be affected by the internationalization degree and the firm size. These factors are used as control variables in a seemingly unrelated regression analysis.

\section{The Market value (Tobin's q.)}

The market value of a firm is defined as the sum of the total market capitalization of a firm as of the end of the calendar year plus the book value of its debt. It is measured as below:

Tobin's $q=\frac{\text { Value Market of Assets }+ \text { Value Market of Debt }}{\text { Total Assets }}$. 


\section{Earnings management (EM)}

The earnings management is measured by the accruals volume. Total accruals are calculated as being the difference between the net income and the flows coming from the operating activities. Since managers have more capacity to control and manipulate the short-term accruals, we limit our study on the working capital accruals. In this way, total accruals are measured as below:

total accruals $=[($ short-term assets - cash and equivalent $)-$ (short-term liability - short-term bank debt)] -

(amortization and depreciation).

The total accruals include discretionary and non-discretionary accruals. The earnings management may be limited only to the discretionary accruals. For this reason, we adopted the Jones' (1991) model for distinguishing between discretionary and non-discretionary accruals. The advantage of this model is that it allows to test a wide variety of earnings management inside the firm. The model adopted by Jones (1991) is presented below:

$$
\begin{aligned}
& \frac{\text { Total Accruals }_{i t}}{\text { Total assets }_{i t-1}}=\alpha_{0} \frac{1}{\text { Total assets }_{i t-1}}+ \\
& \alpha_{1} \frac{\text { net revenue Variation }_{i t}}{\text { Total assets }_{i t-1}}+ \\
& \alpha_{2} \frac{\text { immobilization Value }_{i t}}{\text { Total assets }_{i t-1}}+\varepsilon_{i t} .
\end{aligned}
$$

Discretionary and non-discretionary accruals are obtained from the estimation of this model. Jones (1991) considers that discretionary accruals are measured by the error factor. The discretionary and non-discretionary accruals measures are obtained from these equations:

$$
\begin{aligned}
& \frac{\text { Non-Discretionary Accruals }}{\text { Total assets }_{i t-1}}=\hat{\alpha}_{0}+ \\
& \hat{\alpha_{1}} \frac{\text { net revenue Variation }_{i t}}{\text { Total assets }_{i t-1}}+ \\
& \hat{\alpha_{2}} \frac{\text { immobilization Value }_{i t}}{\text { Total assets }_{i t-1}} ; \\
& \frac{\text { Discretionary Accruals }_{\text {Total assets }}}{i t-1}=\frac{\text { Total Accruals }_{i t}}{\text { Total }_{\text {assets }}}- \\
& \left(\hat{\alpha}_{i t-1}+\hat{\alpha}_{1} \frac{\text { net revenue Variation }_{i t}}{\text { Total assets }_{i t-1}}+\right. \\
& \left.\hat{\alpha}_{2} \frac{\text { immobilization Value }_{i t}}{\text { Total assets }_{i t-1}}\right) .
\end{aligned}
$$

\section{R\&D decentralization (DecR\&D)}

This variable indicates the part of $R \& D$ expenditure that the firm engages in the subsidiaries units. It is already measured as $\frac{\text { Foreign } R \& D \text { Expenditure }}{\text { Total Sales }}$.

\section{$R \& D$ centralized (CentR\&D)}

The centralized $R \& D$ investment spending indicates the part of $R \& D$ expenditure that the firm engages in the headquarters units. It is already measured as Internal $R \& D$ Expenditure Total Sales

\section{Firm size (Size)}

In line with Griliches (1980), total assets are used as a proxy for firm size. It is measured by the total assets logarithm. This measure is adopted since the activities of the big-size companies are often diversified and depend less on the success of a particular project, by comparison with the small-size companies (Lehmann and Neuberger 2000). This variable is already measured as Firm size $=\ln$ (Total Assets).

\section{Firms Internationalization degree (DI)}

The internationalization degree is traditionally measured by the foreign sales ratio (Michel and Shaked 1986), the foreign assets ratio, the foreign tax ratio (Lee and Kwok 1988) or outward direct foreign investment (Koechlin 1995). In our case, two ratios are combined to measure the internationalization degree as the measure used by Doukas and Pantzalis (2003), i. e. foreign sales ratio and foreign assets ratio.

\subsection{Sample data}

There are 250 firms' data available in the SBF 250 French index market. The data used in the testing model is identified from the "Ernstrade" database that provides the companies' name list about different market indexes. This paper includes all companies provided by the SBF 250 French index market whose financial statement data are available for the 5-year period from 2002 to 2006. Using annual report, the final sample of 92 multinational companies is obtained after elimination of the financial firms or those whose data is empty. In sum, our sample includes 460 firm-year observations.

\subsection{The models}

To test the effect of the R\&D decentralization on the shareholders' wealth and on the earnings management, the seemingly unrelated regression models were used: 
$\left\{\begin{array}{l}\text { Tobin's } \\ i t\end{array}=\alpha_{0}+\alpha_{1} \operatorname{DecR}_{2} \mathrm{D}_{i t}+\alpha_{2}\right.$ CentR $_{i t}+\alpha_{3} \mathrm{DI}_{i t}+\alpha_{4} \operatorname{Size}_{i t}+\varepsilon_{i t}$ $\left\{\mathrm{EM}_{i t}=\beta_{0}+\beta_{1}{\operatorname{DecR} \& \mathrm{D}_{i t}+\beta_{2} \text { CentR\&D }}_{i t}+\beta_{3} \mathrm{DI}_{i t}+\beta_{4}\right.$ Size $_{i t}+\varepsilon_{i t}$,

where:

- Tobin's $\mathrm{q}_{i t}$ : is the measure of the firm value associated with the firm " $i$ " in the time period " $t$ ";

- EM: is the total accruals managed in the firm " $i$ " in the time period " $\mathrm{t}$ ";

- DecR\& $\mathrm{D}_{\mathrm{it}}$ : is the portion of the R\&D expenditure allowed at subsidiaries of the firm " $i$ " in the period " $t$ ";

- CentR\& $\mathrm{D}_{\mathrm{it}}$ : is the sum of cash that the firm "i" provides to its subsidiaries in the period " $t$ ";

- Size $_{\mathrm{it}}$ : is the size of the firm "i" in the time period " $t$ ";

- $\mathrm{DI}_{\mathrm{it}}$ : is the internationalization degree of the firm " $i$ " in the time period " $t$ ".

\section{Empirical results and discussion}

Table 1 presents the correlation coefficients between the various explanatory variables used in the model.

Table 1. Correlation coefficient

\begin{tabular}{|c|c|c|c|c|}
\hline & Dec & R\&D & Size & DI \\
\hline Dec & 1.0000 & & & \\
\hline $\mathrm{R} \& \mathrm{D}$ & 0.3898 & 1.0000 & & \\
\hline Size & 0.2261 & -0.0236 & 1.0000 & \\
\hline DI & 0.6044 & 0.0234 & 0.4076 & 1.0000 \\
\hline
\end{tabular}

The results presented in this Table show that there is not any coefficient which exceeds the 0.7 level as the limit traced by Kervin (1992). If the coefficient is higher than 0.7 , a problem of multicolinearity will exist.
This problem arises when there is a strong correlation between two independent variables. In this study, the results presented in Table 1 indicate that there is no coefficient of correlation (for any $i \neq j$ ) that is higher than 0.7 which indicates the absence of multicolinearity problem between the explanatory variables.

Table 2 shows regression results of market value of the MNCs and those of the earnings management. The results show a significant and positive relationship between R\&D expending and market value as measured with the "Tobin's q" if the R\&D activities were centralized. This result indicates that the centralized R\&D investments may enhance shareholders' wealth.

The R\&D activity is the intangible assets which may produce future growth opportunities. Because they are expected to generate future financial resources, firms characterized by significant R\&D expenditures should exhibit high market value. The results presented in Table (2) indicate that investors evaluate the R\&D investment with a long-term perspective. It implies, particularly, that share-price may be significantly and positively related to the increase of the R\&D spending.

These same results show that $R \& D$ decentralization affects negatively the shareholders' wealth. This result indicates that despite that it may be beneficial on the organizational efficiency level, the decentralization of the R\&D investment may affect negatively the shareholders' wealth. However, in opposition, it may likely increase the managers' entrainment. The R\&D decentralization increases the informational asymmetry between shareholders and managers which will give grounds for earnings management.

Table 2. The seemingly unrelated regression models result

\begin{tabular}{|c|c|c|c|c|}
\hline \multirow{2}{*}{ Variables } & \multicolumn{2}{|c|}{ Tobin's q } & \multicolumn{2}{|c|}{ EM } \\
\hline & coef. & Z-statistic & coef. & z-statistic \\
\hline Dec & $-1.497718 * * *$ & -5.45 & $2.354238 * * *$ & 3.98 \\
\hline $\mathrm{R} \& \mathrm{D}$ & $3.095167 * * *$ & 4.83 & $0.4931037 * *$ & 2.38 \\
\hline Size & 0.0132998 & 0.66 & -0.0061633 & -1.27 \\
\hline DI & $1.434651 * * *$ & 5.58 & $0.0479941 * * *$ & 9.94 \\
\hline cons & -0.233197 & -1.03 & $0.6246446 * * *$ & 10.44 \\
\hline R-square & \multicolumn{2}{|c|}{0.1567} & \multicolumn{2}{|c|}{0.4179} \\
\hline Obs. & \multicolumn{2}{|c|}{960} & \multicolumn{2}{|c|}{960} \\
\hline
\end{tabular}

$* * *$ : Significant level 1\%

$* *$ : Significant level 5\%

* : Significant level 10\% 
Although R\&D decentralization contributes significantly to the organizational efficiency and it may induce the risk failure transfer from the headquarters to the subsidiaries located in the country, in which the failure procedures are more flexible, the effect on the firm market value is significantly negative. The potential investors evaluate the investment decentralization with more prudence because it may increase the autonomy of the managers on the total assets. For this reason, shareholders will prefer not to disperse the $R \& D$ investment. This behaviour is justified by the perception of the positive relationship between informational asymmetry and R\&D geographical diversification which is at the origin of the earnings management, which may enhance the managers' entrainment and induce the shareholders' wealth destruction.

In these terms, managers increase the $R \& D$ decentralization degree because they will exploit the information asymmetry between them and investors to smoothing economic income and wanting these latters to perceive that the firm is less risky and/or that it performs well. This view, is previously defended by Lambert (1984), Hughes and Schwartz (1989) and Trueman and Titman (1989) who show that the "risk averse" managers have an incentive to smooth the economic earnings and may use the informational asymmetry to influence the way the investors perceive the firm's performance. These arguments justify the negative relationship between the $\mathrm{R} \& \mathrm{D}$ diversification and the firm market value and the positive relationship between the earnings management and the $R \& D$ decentralization. The investors anticipate the managers' opportunist behaviour and will decrease the stock-price which will cause the shareholders' wealth destruction.

Taken together, these arguments allow us to reject our first assumption and to validate the second one. In this sense, the R\&D diversification induces the destruction of the shareholders' wealth and the increase of the managers' one. Managers disperse the R\&D investment for increasing the informational asymmetry. This behaviour gives them more autonomy which is likely to help them manage the economic results to increase their own wealth and destruct the shareholder's one.

\section{Conclusions}

While the positive and negative attributes of R\&D in the firm's performance have been theoretically and empirically examined, in this paper we examine the impact of R\&D decentralization on the performance of the MNCs. We integrate the earnings management to explain the negative impact of this strategy on share- holders' wealth. Specifically, we analyse the effects of the R\&D investment decentralization on the firm market value using a sample of 460 firm-year observations for multinational firms over the 2002-2006 period.

Our results show that the relationship between $R \& D$ geographic diversification and shareholders' wealth is significantly negative. The decentralization decision should be primarily motivated by the desire to increase the informational asymmetry to facilitate the earnings management. This argument indicates that managers pursue a non-wealth maximizing behaviour. The decentralization is motivated, again, by the desire to increase the firm size in order to maximize the managers' utilities rather than serve the shareholders' interests. These results are consistent with the view that the informational asymmetry is associated with the geographic diversification intensity and that the managers use this asymmetry to increase their own wealth and destruct the shareholder's one.

\section{References}

Bae, S. C.; Noh, S. 2001. Multinational corporations versus domestic corporations: a comparative study of R\&D investment activities, Journal of Multinational Financial Management 11: 89-104.

Chaney, P. K. and Lewis, C. M. 1995. Earnings management and firm valuation under asymmetric information, Journal of Corporate Finance 1: 319-345.

Chauvin K. W.; Hirschey, M. 1993. Advertising, R\&D expenditures and the market value of the firm, Financial Management 22(4): 128-140.

Doukas, J. A.; Pantzalis, C. 2003. Geographic diversification and agency costs of debt of multinational firms, Journal of Corporate Finance 9: 59-92.

Griliches, Z. 1980. Returns to research and development expenditure in the private sector, in Kendrick, J. W.; Vaccara, B. N. (Eds.). New Developments in Productivity Measurement and Analysis. The University of Chicago Press, Chicago.

Hayek, F. A. 1945. The use of scientific knowledge in society, American Economic Review 35(4).

Hughes, P. J. and Schwartz, E. S. 1989. The LIFO/FIFO choice: an asymmetric information approach, Journal of Accounting Research (supplement): 41-58.

Jensen, M. C.; Meckling, W. 1992. Specific and general knowledge, and organizational structure, in Werin, L., Wijkander, H. (Eds.). Contract Economics. Blackwell, 251-274.

Jensen, M. C.; Murphy, K. J. 1990a. Performance pay and top management incentives, Journal of Political Economy April: 225-265. 
Jones, J. 1991. Earnings management during import belief investigations, Journal of Accounting Research 29: 193-228.

Kervin, J. B. 1992. Methods for Business Research. New York: Harpet Collins.

Klein, A. 2002. Audit committee, board of directors characteristics, and earnings management, Journal of Accounting and Economics 33: 375-400.

Koechlin, T. 1995. The globalization of investment, Contemporary Economic Policy 13 (January): 92-100.

Kuemmerle, W. 1999a. The drivers of foreign direct investment into research and development: an empirical investigation, Journal of International Business Studies 30(1):1-24.

Kuemmerle, W. 1999b. Foreign direct investment in industrial research in the pharmaceutical and electronics industries-results from a survey of multinational firms, Research Policy 28: 179-193.

Lakonishok, J.; Shleifer, A. and Vishny, R. 1994. Contrarian investment, extrapolation, and risk, Journal of Finance 49: 1541-1578.

Lambert, R. A. 1984. Income smoothing as rational equilibrium behavior, The Accounting Review 59 (4 October): 604-618.

Lee, K. C.; Kwok, C. Y. 1988. Multinational corporations vs. domestic corporations: International environmental factors and determinants of capital structure, Journal of International Business Studies 19 (summer): 195-217.

Lehmann, E.; Neuberger, D. 2000. Do lending relationship matter? Evidence from bank survey data in Germany. Working Paper, University of Konstanz, and University of Rostack, 45-59.
Michel, A. and Shaked, I. 1986. Multinational corporations vs. domestic corporations: Financial performance and characteristics, Journal of International Business Studies 17: 89-99.

Morck, R. et al. 1990. Do managerial objectives drive bad acquisitions? Journal of Finance 45: 31-48.

Myers, S. 1977. Determinants of corporate borrowing, Journal of Financial Economics 5: 147-175.

Pearce, R. D.; Singh, S. 1992. The internationalisation of research and development: a firm-level analysis of determinants, in Pearce, R. and Singh, S. (Eds.). Globalizing Research and Development. The Macmillan Press Ltd, London.

Ronstadt, R. C. 1978. International R\&D: the establishment and evolution of research and development abroad by seven US multinationals, Journal of International Business Studies 9: 7-24.

Shleifer, A.; Vishny, R. W. 1989. Management entrenchment: the case of manager-specific investments, Journal of Financial Economics 25: 123-140.

Trueman, B.; Titman, S. 1989. An explanation for accounting income smoothing, Journal of Accounting Research (supplement): 127-139.

Xie, Biao.; Davidson, W. N. and DaDalt, P. 2003. Earnings management and corporate governance: the role of board and the audit committee, Journal of Corporate Finance 9: 295-316.

Zhang, X. F. 2007. Accruals, Investment, and the Accrual Anomaly. Working paper (SSRN-id87376[1]). Available from Internet: <www.ssrn.com>. 